\title{
The awareness of primary caregivers in South Africa of the human rights of their children with intellectual disabilities
}

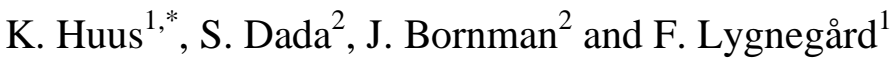 \\ ${ }^{1}$ School of Health Sciences, CHILD Research Group, Jönköping, Sweden \\ ${ }^{2}$ Centre for Augmentative and Alternative Communication, University of Pretoria, Pretoria, South \\ Africa \\ * Correspondence: \\ Karina Huus, School of Health Sciences, CHILD Research Group, P.O. Box 1026, Jönköping SE 551 \\ 11 , Sweden \\ E-mail: karina.huus@ju.se
}

\begin{abstract}
Background: Besides the right to freedom, human rights can be seen as a basic requirement also for the maintenance of human dignity and the opportunity to thrive - particularly in the case of children with disabilities. It is imperative to explore primary caregivers' awareness of the human rights of their children with intellectual disabilities in view of the role they may play in either facilitating or restricting these rights. This paper explores the awareness of 219 primary caregivers of the human rights of their children with intellectual disabilities.
\end{abstract}

Method: A descriptive survey design was used with a custom-designed questionnaire that employed a deductive content analysis based on the articles of the United Nations Convention on the Rights of a Child. Comparisons were drawn between the awareness of primary caregivers from urban and those from rural areas.

Results: The majority (85.5\%) of participants agreed that their child with intellectual disability had rights. Three broad kinds of rights were mentioned (in descending order): provision rights, protection rights and participation rights. Participants from both urban and rural areas mentioned education (a provision right) most frequently. However, participants from urban areas were more aware of the different rights that existed than were their counterparts from rural areas.

Conclusion: Primary caregivers in both rural and urban areas are aware of the rights of their children with disabilities, although there are significant differences between them.

Key words: Children's rights, Disability, Parent perceptions, Participation rights, Protection rights, Provision rights. 


\section{Introduction}

Besides the right to freedom, human rights are seen as basic requirements for the maintenance of human dignity and the opportunity to thrive (Ruck et al. 1998). Furthermore, rights imply entitlement to such things as food, shelter, a non-threatening physical environment, security, health, knowledge, work, freedom of conscience, freedom of expression, freedom of association and self-determination (Bayles 1981).

The United Nations Convention on the Rights of a Child (CRC) recognises caregivers' role as the guardians of their children's rights. Woodhouse (2006) also remarks that the intent of the CRC was not to affect or take rights away from caregivers, but rather to retain the balance between the rights of children and the rights of families. By acknowledging that children have rights, caregivers acknowledge their responsibility to take care of their children's needs and to protect them from harm (Dillen 2006).

The rights of children should never be considered separately from the rights of their caregivers (Klinck et al. 1999). Primary caregivers of children with special needs are obliged to be well informed when they take decisions concerning their children (Saleh 1999). The caregivers' perspective on children's rights insists that children with disabilities need specific care and they are often unable to implement their own rights (Dillen 2006).

The views of primary caregivers are also important in the understanding of children's rights since the caregivers are in a favourable position to either fulfil or restrict their children's provision, protection and participation rights (Cherney and Shing 2008; Day et al. 2006; Ruck et al. 2002).

Lowden (2002) argues that adult beliefs about children's rights influence the latter's opportunities for self-determination. As some researchers have noted, in the case of young children who are economically, psychologically and physically dependent on their primary caregivers, children's rights are fulfilled by the primary caregivers on behalf of the child, rather than through the child's own intervention (Cherney and Shing 2008; Peterson-Badali et al. 2003).

In respect of typically developing children in South Africa, there is a paucity of research regarding the perception that these children have of their rights. Venter, Kok and Myburgh (1996) investigated the degree to which children's awareness of their rights was promoted by the school system. Results from their study showed that more Afrikaansspeaking than English-speaking participants felt that children had been made increasingly aware of their rights by the time they reached their final school year. 
The current research forms part of a larger project that examined both parental and child perspectives concerning the rights of children with intellectual disability in South Africa.

\section{Research method}

\section{Design}

This research used a quantitative descriptive survey design. A custom-designed questionnaire was employed (Donohue et al. 2014a).

\section{Context}

The study was conducted in South Africa, a country rich in cultural, religious, racial and ethnic diversity. However, South Africa continues to face enormous challenges imposed by the legacy of apartheid policies, including limited access to education, social and health services. The population suffers from high maternal and infant mortality rates; high prevalence of communicable diseases such as HIV/Aids, tuberculosis (TB) and malaria; poor literacy levels; high levels of unemployment, and many people living below the poverty line (Naidoo 2008; Statistics South Africa 2011). Metropolitan cities in three provinces Gauteng, KwaZulu-Natal and Limpopo - were included in this study. The respondents in these provinces are described in terms of a number of aspects in Table 1, based on figures extrapolated from the 2011 South African census data.

Table 1 Context description

\begin{tabular}{|l|l|l|l|}
\hline Aspect & Gauteng & KwaZulu-Natal & Limpopo \\
\hline Context classification & Mostly urban & Mostly rural & Mostly rural \\
\hline Geographical land area & $18178 \mathrm{~km}^{2}$ & $94361 \mathrm{~km}^{2}$ & $125754 \mathrm{~km}^{2}$ \\
\hline Population size & 12272263 & 10267300 & 5404868 \\
\hline $\begin{array}{l}\text { Predominant languages } \\
\text { spoken as first language }\end{array}$ & $\begin{array}{l}2390036 \text { isiZulu } \\
1603464 \text { English } \\
1502940 \text { Afrikaans }\end{array}$ & $\begin{array}{l}7901932 \text { isiZulu } \\
1337606 \text { English } \\
796841 \text { isiXhosa }\end{array}$ & $\begin{array}{r}2826464 \text { Sepedi } \\
906325 \text { Xitsonga } \\
892809 \text { Tshivenda }\end{array}$ \\
\hline $\begin{array}{l}\text { Childhood poverty (Less } \\
\text { than R600 / }\end{array}$ & $35.3 \%$ & $67.5 \%$ & $77.1 \%$ \\
\hline $\begin{array}{l}\text { UnSUSD per month) } \\
\text { household }\end{array}$ & $16 \%$ & & \\
\hline *Formal dwelling & $79.8 \%$ & $42.4 \%$ & $49.5 \%$ \\
\hline Tap water available & $98.2 \%$ & $71.6 \%$ & $89.8 \%$ \\
\hline Electricity available & $87.4 \%$ & $85.9 \%$ & $86.0 \%$ \\
\hline$* *$ Access to indoor toilet & $96.3 \%$ & $77.9 \%$ & $87.3 \%$ \\
\hline Persons with disabilities & $5.3 \%$ & $8.4 \%$ & $6.9 \%$ \\
\hline
\end{tabular}

*Formal dwelling refers to a brick house, separate flat or apartment in a block of flats, semi-detached house.

** Those who did not have indoor toilets, made use of bucket toilets. 


\section{Participants}

Participants were recruited from 11 special schools that serve children with mild to moderate intellectual disabilities in South Africa. These included four schools in rural areas (three in KwaZulu-Natal and one in Limpopo), as well as seven schools in an urban area (Gauteng). A total of 234 primary caregivers met the criteria, namely parenting a child between the ages of 8.0 and 14.11 (years; months).

Of these 234 potential participants, 15 were excluded because of reasons such as the following: they provided incomplete data; they parented children in a group home; they did not return the questionnaire in time; they did not give consent. Table 2 provides an overall description of the primary caregivers as participants in the study.

Table 2 Participant description

\begin{tabular}{|c|c|c|c|}
\hline Demographic information of primary caregivers & $\begin{array}{l}\text { Urban } \\
\mathrm{n}=105\end{array}$ & $\begin{array}{l}\text { Rural } \\
\mathrm{n}=114\end{array}$ & $\begin{array}{l}\text { Total } \\
\mathbf{N}=219\end{array}$ \\
\hline Relationship: Married or in a stable relationship & $64.8 \%$ & $59.7 \%$ & $61.2 \%$ \\
\hline Education: Education of longer than 12 years & $56.3 \%$ & $46 \%$ & $50.9 \%$ \\
\hline $\begin{array}{l}\text { Income: Total household income of less than R60 } 000 \text { per year } \\
\text { (approximately 5 400USD) }\end{array}$ & $52.1 \%$ & $76.4 \%$ & $65.2 \%$ \\
\hline Work status: In full-time or part-time employment & $59 \%$ & $51.8 \%$ & $55.3 \%$ \\
\hline Number of people living in the household: mean value & 5.17 & 5.60 & 5.39 \\
\hline \multicolumn{4}{|l|}{ Relation to the child: } \\
\hline Father & $18.4 \%$ & $16.8 \%$ & $17.6 \%$ \\
\hline Mother & $58.3 \%$ & $61.1 \%$ & $59.7 \%$ \\
\hline Other (e.g. grandparent, sibling, aunt) & $23.3 \%$ & $22.1 \%$ & $22.7 \%$ \\
\hline \multicolumn{4}{|l|}{ 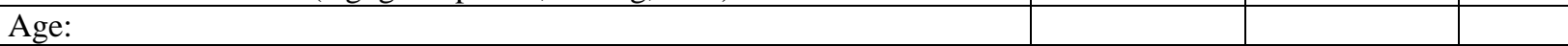 } \\
\hline Mean value (years) & 39.83 & 39.88 & 39.86 \\
\hline Range (years) & $25-67$ & $25-65$ & $25-67$ \\
\hline
\end{tabular}

\section{Questionnaire}

A questionnaire was developed in English, piloted and revised (Appendix A). It was translated through a process of blind-back-translation into Afrikaans, isiZulu and Xitsonga, the other languages commonly spoken in the study area (Donohue et al. 2014a; 2014b). The questionnaire comprised the following three different sections:

Section 1 asked about demographic factors related to socioeconomic status, such as the participant's age, education, the household size and family income.

Section 2 focused on child characteristics and was based on the Ten Question Questionnaire (TQQ), a standardised screening questionnaire administered to parents to detect moderate to severe neurologic impairments and disabilities in children (Zaman et al. 1990). The TQQ is a rapid, low-cost screening measure that has demonstrated reliability in both low- and middle-income countries (Durkin et al. 1995). 
Section 3 (based on Article 23 of the CRC) included a number of close-ended questions with a Yes/No answer that probed participants' awareness of the fact that their children with intellectual disability actually had rights. If participants answered "yes", they were requested to list and prioritise those children rights they could think of.

\section{Data collection procedures}

The study was performed in accordance with the Helsinki Declaration. Ethical approval was obtained from the relevant higher education facility, as well as from the relevant Provincial Departments of Education, school principals, teachers and primary caregivers of children with intellectual disability. The consent letter and questionnaire were sent to primary caregivers via their children. The teacher wrote a short note in each child's homework book to request that primary caregivers complete the consent form and questionnaire. Children received a small packet of sweets as a token of appreciation on returning the documents, irrespective of whether the primary caregivers had given consent. A week later a reminder was sent, which had a positive impact on the return rate. The questionnaires were collected three weeks after distribution.

\section{Data analysis and reliability}

The three fieldworkers who collected the data were bilingual (speaking one of the three target languages as well as English). They independently provided a word-for-word translation of survey responses into English. Two independent translators and one of the authors then also translated the comments into English. The two English versions were subsequently compared and if any discrepancies were found, they were discussed until a final English version of the survey responses was agreed upon. Slight differences were noted, which could typically be attributed to the use of synonyms, and therefore consensus on the most appropriate translation was reached easily.

An expert panel, which was moderated by one of the authors, linked participant responses to CRC articles by means of deductive content analysis based on the CRC articles. The panel consisted of seven members (six female and one male), all with more than five years' experience in the disability field, and all familiar with the CRC. The panel's discussions were conducted in English and all members were fluent in English. Of the panel members, three were speech-language pathologists, two were teachers, one was an occupational therapist, and one a disability advocate. 
The different CRC articles were displayed electronically on a big screen. The moderator read out each participant's response and asked panel members to independently consider the response and link it to one of the CRC articles. The moderator subsequently asked each panel member to indicate the CRC article selected. In exceptional cases where a $100 \%$ agreement was not evident from the onset, the different panel members were asked to justify the specific article selected. The discussion continued until full consensus was reached. This resulted in rules being created as the process continued, for instance when the participant's response was only "education", it was regarded as Article 28, but when it was more comprehensive, e.g. "Education to make sure that my child reaches his full potential", it was regarded as Article 29. These rules were applied consistently throughout the datalinking procedure.

The expert panel then linked the $22 \mathrm{CRC}$ articles mentioned by participants according to participation, protection and provision rights as described by Alderson (2008). The panel first did this individually, and then discussed their opinions until consensus was reached.

\section{Results}

Table 3 shows that $85.8 \%$ of primary caregivers were of the opinion that their child with intellectual disability possessed rights. However, the flipside was also true, since $14.2 \%$ of the primary caregivers actually reported that their children with disabilities did not have rights. A statistically significant difference in responses $(\mathrm{p}<0.001)$ between primary caregivers was found, and more urban primary caregivers believed that their children with intellectual disabilities had rights when compared to primary caregivers in rural contexts. Similarly, statistically significant differences $(p<0.001)$ were found between the responses of urban and rural primary caregivers who had to list the rights of their child with disabilities.

Table 3. Primary caregivers' perceptions about children's rights

\begin{tabular}{|l|l|l|l|l|l|l|}
\hline Question & $\begin{array}{l}\text { Urban } \\
\mathbf{n = 1 0 5}\end{array}$ & $\begin{array}{l}\text { Rural } \\
\mathbf{n = 1 1 4}\end{array}$ & $\begin{array}{l}\text { Total } \\
\text { N=219 }\end{array}$ & p-value & X2 & $\begin{array}{c}\text { Difference } \\
\mathbf{9 5 \%} \text { CI }\end{array}$ \\
\hline $\begin{array}{l}\text { Are you of the opinion that your child has rights? } \\
\text { (Yes) (Chi-square) }\end{array}$ & $94.9 \%$ & $78.1 \%$ & $85.8 \%$ & $<0.001$ & 12.284 & \\
\hline $\begin{array}{l}\text { The mean number of rights mentioned by } \\
\text { primary caregivers (T-test) }\end{array}$ & 3.34 & 2.37 & 2.84 & $<0.001$ & & $0.47-1.48$ \\
\hline
\end{tabular}

From Table 3, it is evident that an average of 3.3 rights (ranging between 0 and 7) were mentioned by primary caregivers who came from an urban area, while an average of 2.6 rights (ranging between 0 and 6) were mentioned by primary caregivers from the rural areas. 
Table 4 presents the responses of only those 171 primary caregivers who answered positively as to whether their children had rights (seven participants did not answer this particular question). It places the rights in order of how frequently they were mentioned. The table shows the 22 different articles of the CRC to which primary caregiver responses were linked, and the kind of rights involved (protection, provision or participation rights). It furthermore compares the responses of primary caregivers from rural areas and from urban areas and shows which of these differences were significant.

Table 4 Child rights mentioned by primary caregivers $(\mathrm{N}=182)$

\begin{tabular}{|c|c|c|c|c|c|c|c|}
\hline \multirow{2}{*}{$\begin{array}{l}\text { Child rights } \\
\text { mentioned by } \\
\text { primary } \\
\text { caregivers }\end{array}$} & \multirow{2}{*}{$\begin{array}{l}\text { Total number } \\
\text { of times the } \\
\text { right was } \\
\text { mentioned }\end{array}$} & \multirow[t]{2}{*}{$\begin{array}{l}\text { Article in } \\
\text { CRC }\end{array}$} & \multirow[t]{2}{*}{$\begin{array}{l}\text { Type of right: } \\
\text { Provision; Protection; } \\
\text { Participation }\end{array}$} & \multicolumn{2}{|c|}{$\begin{array}{l}\text { Type of area } \\
\text { where primary } \\
\text { caregivers lived }\end{array}$} & \multirow{2}{*}{$\begin{array}{l}\text { Chi- } \\
\text { square } \\
\text { X2 }\end{array}$} & \multirow{2}{*}{$\begin{array}{l}\text { Comparison } \\
\text { between rural } \\
\text { and urban areas } \\
\text { p-value }\end{array}$} \\
\hline & & & & Urban & Rural & & \\
\hline Education & 129 & 28 & Provision & 55 & 74 & 3.546 & 0.060 \\
\hline $\begin{array}{l}\text { Decent standard of } \\
\text { living }\end{array}$ & 65 & 27 & Provision & 36 & 29 & 2.050 & 0.152 \\
\hline Healthcare & 58 & 24 & Provision & 32 & 26 & 1.651 & 0.199 \\
\hline $\begin{array}{l}\text { Right to maximise } \\
\text { child's potential } \\
\text { for development }\end{array}$ & 42 & 6 & Provision & 26 & 16 & 4.057 & $0.044 *$ \\
\hline $\begin{array}{l}\text { Education to self- } \\
\text { actualise child }\end{array}$ & 28 & 29 & Provision & 22 & 6 & 12.066 & $0.001 *$ \\
\hline $\begin{array}{l}\text { Children with } \\
\text { disabilities should } \\
\text { have a decent life }\end{array}$ & 19 & 23 & Provision & 11 & 8 & 0.825 & 0.364 \\
\hline Social security & 6 & 26 & Provision & 3 & 3 & 0.010 & 0.919 \\
\hline $\begin{array}{l}\text { Right to be with or } \\
\text { be in contact with } \\
\text { primary caregivers }\end{array}$ & 7 & 9 & Provision & 4 & 3 & 0.245 & 0.621 \\
\hline $\begin{array}{l}\text { Right to } \\
\text { information and } \\
\text { expression }\end{array}$ & 6 & 13 & Provision & 2 & 4 & 0.528 & 0.468 \\
\hline $\begin{array}{l}\text { Right to thought } \\
\text { and religion }\end{array}$ & 6 & 14 & Provision & 5 & 3 & 3.095 & 0.079 \\
\hline Right to privacy & 6 & 16 & Provision & 6 & 0 & 6.698 & $0.010 *$ \\
\hline $\begin{array}{l}\text { Right to an } \\
\text { identity, including } \\
\text { nationality and } \\
\text { family relations }\end{array}$ & 4 & 8 & Provision & 4 & 0 & 4.424 & $0.035 *$ \\
\hline \multirow{2}{*}{$\begin{array}{l}\text { Right to be a } \\
\text { minority and } \\
\text { practise own } \\
\text { culture }\end{array}$} & 1 & 30 & Provision & & 1 & 0.925 & 0.336 \\
\hline & 377 & \multicolumn{6}{|c|}{ Total number of times provision rights are mentioned } \\
\hline \multirow[t]{2}{*}{ Right to play } & 17 & 31 & Participation & 9 & 8 & 0.184 & 0.668 \\
\hline & 17 & \multicolumn{6}{|c|}{ Total number of times participation rights are mentioned } \\
\hline
\end{tabular}




\begin{tabular}{|c|c|c|c|c|c|c|c|}
\hline \multirow[t]{2}{*}{$\begin{array}{l}\text { Child rights } \\
\text { mentioned by } \\
\text { primary caregivers }\end{array}$} & \multirow[t]{2}{*}{$\begin{array}{l}\text { Total number of } \\
\text { times the right } \\
\text { was mentioned }\end{array}$} & \multirow[t]{2}{*}{ Article in CRC } & \multirow[t]{2}{*}{$\begin{array}{l}\text { Type of right: } \\
\text { Provision; } \\
\text { Protection; } \\
\text { Participation }\end{array}$} & \multicolumn{2}{|c|}{$\begin{array}{l}\text { Type of area where } \\
\text { primary caregivers } \\
\text { lived }\end{array}$} & \multirow{2}{*}{$\begin{array}{l}\text { Chi- } \\
\text { square } \\
\text { X2 }\end{array}$} & \multirow{2}{*}{$\begin{array}{l}\text { Comparison } \\
\text { between rural } \\
\text { and urban areas } \\
\text { p-value }\end{array}$} \\
\hline & & & & Urban & Rural & & \\
\hline $\begin{array}{l}\text { Right to protection } \\
\text { from the State } \\
\text { when maltreated }\end{array}$ & 70 & 21 & Protection & 45 & 25 & 11.007 & $0.001 *$ \\
\hline $\begin{array}{l}\text { Best interest of } \\
\text { child should be } \\
\text { considered }\end{array}$ & 45 & 3 & Protection & 23 & 22 & 0.227 & 0.633 \\
\hline $\begin{array}{l}\text { No discrimination } \\
\text { based on race, sex, } \\
\text { disability, etc. }\end{array}$ & 44 & 2 & Protection & 30 & 14 & 9.035 & $0.003 *$ \\
\hline $\begin{array}{l}\text { Freedom from } \\
\text { abuse and } \\
\text { maltreatment }\end{array}$ & 10 & 19 & Protection & 4 & 6 & 0.265 & 0.607 \\
\hline $\begin{array}{l}\text { No illicit transfer } \\
\text { of children abroad }\end{array}$ & 1 & 11 & Protection & 1 & & 1.091 & 0.296 \\
\hline $\begin{array}{l}\text { Protection from } \\
\text { explorative work }\end{array}$ & 1 & 36 & Protection & 1 & & 1.091 & 0.296 \\
\hline \multirow{2}{*}{$\begin{array}{l}\text { Protection from } \\
\text { sexual exploitation } \\
\text { and abuse }\end{array}$} & 1 & 34 & Protection & & 1 & 0.925 & 0.336 \\
\hline & 172 & \multicolumn{6}{|c|}{ Total number of times protection rights are mentioned } \\
\hline
\end{tabular}

*P-values $<0.05$ were considered as a statistically significant difference between primary caregivers in urban vs. rural areas.

There was a statistically significant difference $(\mathrm{p} \leq 0.05)$. in responses between urban and rural primary caregivers regarding six of the 22 rights. Of these six rights, four related to provision rights, namely the right to education for self-actualisation $(\mathrm{p}=0.001)$; the right to an identity, including nationality and family relations $(\mathrm{p}=0.035)$; the right to maximise the child's potential for development $(\mathrm{p}=0.044)$; and the right to privacy $(\mathrm{p}=0.010)$. The other two referred to protection rights, namely the right to protection from the State when maltreated $(\mathrm{p}=0.001)$ and the right to no discrimination based on race, sex, disability, etc. $(\mathrm{p}=0.003)$. None of the participation rights yielded a statistically significant difference between rural and urban primary caregivers.

Regarding the type of rights, provision rights were mentioned the most frequently (377 times), followed by protection rights (172 times), and participation rights were mentioned only 17 times. Furthermore, a range of provision rights were mentioned (linked to 13 CRC articles), protection rights were linked to seven CRC articles and only one could be linked to participation rights (i.e. the right to play).

\section{Discussion}

An important finding of this study was that $85.5 \%$ of the participating primary caregivers were aware of the fact that their child had rights. In a study by Renaut (2002) it was noted 
that primary caregivers were afraid to give children rights, since this would imply giving them power which, in turn, could imply a challenge to the parent-child relationship. In the present study, one of the primary caregivers stated that she did not think that her child has rights, as rights are linked to responsibilities and her child is not able to accept responsibility. Only limited data emerged on the reasons why parents did not think that their child had rights, and it could therefore not be analysed.

\section{Provision rights}

A key finding was that primary caregivers of disabled children who are at school in both urban and rural areas mentioned education (a provision right) most frequently. This is in line with the fact that the provision of appropriate education for children with special disabilities has long been a burning issue in education (Erasmus et al. 2015; Wang 2009). However, this finding may probably be attributed to sampling bias, as all the participants in the present study were parenting children who were currently in school. It evidently demonstrates the fact that primary caregivers believe that school is important and that they must have the opportunity to let their child attend school. It should be stated explicitly that education is a fundamental human right, and unlike the other child rights in the South African Constitution, it is a "non-progressive right", which makes it immediately realisable. Therefore, the view does not apply that economic constraints may prevent all individuals from obtaining the right to education in the short term, while the State progressively makes efforts to assist its citizens to realise these rights (United Nations 1989). The government's obligations regarding education have been organised within the internationally known A4 framework, which focuses on making education 'Available, Accessible, Acceptable and Adaptable' (Tomaševski 2001).

The importance of education is particularly relevant in the South African context as it was estimated that in $2011,8 \%$ of 7 - to 15 -year-old children with disability were not enrolled in school, due to schools being filled to capacity. At the same time, $24 \%$ of 16 - to 18 -yearolds with disability were excluded, inter alia due to schools not being able to cater for the special educational needs of these children. These figures are significantly better than the 2002 data when the corresponding percentages were 27\% and 49\% (Department of Basic Education 2014). Despite this improvement, the Department of Education estimates that around 480036 children with disabilities are currently out of school. According to the Department of Basic Education (2014), there is no reliable system in place to track children 
with disabilities who are currently out of school and/or who have been denied access to school.

Furthermore, no data is available to compare access to education in rural and urban areas, yet rural areas are typically defined by poor infrastructure, lack of services, limited access to education, etc. (Stats SA 2011). As shown in Table 1, disability is more prevalent in rural areas, which is consistent with the cycle of poverty (Emmett 2005) that continues to be a key driver of educational exclusion in South African schools (Gustafsson 2011). It should also be noted that the current study found that the primary caregivers from rural areas had lower levels of education than their urban counterparts. The high number of children with disabilities who were out of school could therefore be attributed to a combination of factors, such as not enough schools, insufficient training of teachers, insufficient provision of infrastructure and teaching and learning materials, as well as an inadequate system for monitoring and measuring disability. Besides these, Loeb and Eide (2004) suggest that some children with disabilities do not attend school as they are hidden from society.

It should, however, be noted that these estimates may fluctuate in rural and urban areas due to overcrowding, as there are few schools and large children populations. These inequities are also more pronounced in rural provinces with high poverty levels such as KwaZulu-Natal and Limpopo (both of which were included in this study) (Tomaševski 2001). In these provinces it was found that many schools were inappropriately constructed (e.g. out of mud); many had no or an unreliable water supply; many had no indoor toilets available; many had no fencing, and many had no communication facilities (internet access, fax machine, landline or telephone). At present, there are not enough special schools to meet the demand, especially in rural areas (Tomaševski 2001) and the available schools often have very long waiting lists. Along with school fees, non-fee costs such as uniforms and transport costs constitute a significant barrier.

\section{Protection rights}

Children with physical, sensory, intellectual or mental health impairments are at an increased risk of becoming victims of violence (UNICEF 2005). Protection rights were mentioned second-most frequently by primary caregivers. Primary caregivers from urban areas were better educated and had a higher income per household, which may have affected how these primary caregivers perceived their child's right to be protected by the State. If the State fails to ensure and protect children's rights and safeguard them against impairments such as 
discrimination, violence and abuse, the children are deprived of their right to have a long life and enjoy a decent standard of living (Degirmencioglu et al. 2008; Rafferty 2007).

\section{Participation rights}

Participation is the right that was least commonly mentioned by the primary caregivers. A possible reason for the low frequency awarded to participation rights could be that primary caregivers believed that their children with disabilities did not really participate in varied social activities (e.g. play). According to Cowart et al. (2004), children with disabilities may require assistance and/or supervision from adults in order to participate in activities outside of the home and school setting. Furthermore, participation in play must occur in a safe environment where the children's involvement does not threaten their health and wellbeing (Lansdown, 2001).

\section{Limitations of the study and recommendations for future research}

A limitation of the current study is the fact that it was restricted to the primary caregivers of children ( $8 ; 0$ to $14 ; 11$ years old) with mild to moderate intellectual disabilities who attend special schools. Thus, the results can be interpreted in a meaningful way for this group only, because age, type of disability as well as school attendance may have an effect on primary caregivers' awareness of children's needs. The sampling technique used might thus have resulted in a biased sample. In addition, the study was conducted in specific geographic areas, hence limiting the generalisability of the study. The fact that parents were asked to list and prioritise rights after having been asked whether they thought their child had rights, could have been interpreted by some participants as being a leading question, resulting in a Hawthorne effect. Furthermore, caregivers in the rural areas had lower levels of education and they may therefore have had difficulty in completing the questionnaire. They may also have had limited knowledge about human rights, child rights and the rights of children with disabilities.

Future research is recommended to focus on qualitative research (i.e. data gleaned for example through in-depth interviews or focus group discussions) in order to understand caregivers' understanding and thinking processes around their children's rights. In addition, this study could be replicated in countries where there are large disparities between rural and urban areas to investigate the extent to which primary caregivers in those areas perceive that 
the basic rights of their children with intellectual disabilities are being met. These studies could correlate access to education and caregiver knowledge of child rights and how they prioritise different kinds of rights.

A further study that evaluates the educational level of the caregiver and its influence on the school enrolment and attendance of the child with disability is recommended. Door-todoor studies, or snowball samples of children with disabilities in particular contexts would allow for data that would also capture the perspectives of parents who have children who are outside the school system. Comparisons with primary caregivers in more developed countries could also be considered. The study could furthermore be replicated by using primary caregivers whose children are younger than $8 ; 0$ or older than $14 ; 11$ years, since research has shown that age is an important variable in the awareness of rights (Donahue et al 2014a).

\section{Conclusion}

This study supports the idea that primary caregivers in both rural and urban areas are aware of the rights of their children with disabilities. Primary caregivers from urban areas are more aware of the different possibilities that exist and they are perhaps better equipped to provide opportunities for their children to exercise their rights than are their counterparts from rural areas. Nevertheless, primary caregivers in rural areas are aware of the rights of their children, particularly with regard to provision rights.

\section{Key Messages}

- This study supports the idea that primary caregivers in both rural and urban areas are aware of the rights of their children with disabilities.

- Primary caregivers from urban areas are more aware of the different types of rights that exist than are their counterparts from rural areas.

- The study's findings seem to support the notion that provision rights are not a prerequisite to participation rights. 


\section{Acknowledgments}

The authors would like to express their gratitude to Dr Ilze Grobbelaar-du Plessis from the Department of Public Law at the University of Pretoria for her invaluable input and comments on this paper. The project was funded by the Swedish International Development Cooperation Agency \#70883.

\section{References}

Alderson, P. (2008) Young children's rights: exploring beliefs, principles and practice, Jessica Kingsley Publishers.

Bayles, M. D. (1981) The false promise of equal rights for mentally retarded persons. Paper presented at the conference Questioning the Unquestionable in the Field of Mental Retardation, London, Canada.

Biegon, J. (2011) The Promotion and Protection of Disability Rights in the African Human Rights System. Aspects of Disability Law in Africa, 53.

Cherney, I. D. \& Shing, Y. L. (2008) Children's Nurturance and Self-Determination Rights: A CrossCultural Perspective. Journal of Social Issues, 64, 835-856.

Children's Institute. (2011) Children count - Abantwana Babalulekile Statistics on Children in South Africa. University of Cape Town: Cape Town. Retrieved from http://www.childrencount.ci.org.za/domain.php?id=6 at 23 October 2015.

Cowart, B. L., Saylor, C. F., Dingle, A. \& Mainor, M. (2004) Social Skills and Recreational Preferences of Children With and Without Disabilities. North American Journal of Psychology, 6.

Day, D. M., Peterson-Badali, M. \& Ruck, M. D. (2006) The relationship between maternal attitudes and young people's attitudes toward children's rights. Journal of Adolescence, 29, 193-207.

De Sas Kropiwnicki, Z. O., Elphick, J. \& Elphick, R. (2014) Standing by themselves: Caregivers' strategies to ensure the right to education for children with disabilities in Orange Farm, South Africa. Childhood, 21, 354-368.

Degirmencioglu, S. M., Acar, H. \& Acar, Y. B. (2008) Extreme forms of child labour in Turkey. Children \& Society, 22, 191-200.

Department of Basic Education. (2014) Annual report 2013/14. Available at: http://www.gov.za/sites/www.gov.za/files/DBE_Annual_Report_2013-14_a.pdf (1 June 2015).

Dillen, A. (2006) Children between liberation and care: ethical perspectives on the rights of children and parent-child relationships. International Journal of Children's Spirituality, 11, 237-250.

Donohue, D. K., Bornman, J. \& Granlund, M. (2014a) Examining the rights of children with intellectual disability in South Africa: Children's perspectives. Journal of Intellectual and Developmental Disability, 39, 55-64. 
Donohue, D. K., Bornman, J. \& Granlund, M. (2014b) Household size is associated with unintelligible speech in children who have intellectual disabilities: A South African study. Developmental Neurorehabilitation, 1-5.

Downing, J. E. \& Macfarland, S. (2012) Severe disabilities (Education and individuals with severe disabilities: Promising practices). In: International Encyclopaedia of Rehabilitation (eds. Stone, J. H. \& Blouin, M.).

Durkin, M., Hasan, Z. \& Hasan, K. (1995) The ten questions screen for childhood disabilities: Its uses and limitations in Pakistan. Journal of Epidemiology and Community Health, 49, 431-436.

Emmett, T. (2005) Disability and poverty. In: E. Alant \& L. Lloyd (Eds.), Augmentative and alternative communication and severe disabilities: Beyond poverty (pp. 68-94). London, United Kingdom: Whurr.

Erasmus, A., Bornman, J. \& Dada, S. (2016) Afrikaans-speaking parents'perception of the rights of their children who have mild to moderate intellectual disabilities: A descriptive investigation. Journal of Child Health Care, 20.2 234-242.

Freeden, M. (1991) Rights. University of Minnesota, Minneapolis, MN.

Freeman, M. \& Nkomo, N. (2006) Guardianship of orphans and vulnerable children. A survey of current and prospective South African caregivers. Aids Care, 18, 302-310.

Gustafsson, I. (2011) Education as a way to strengthen the capacity of rural people to improve food security: Towards a tool for analysis. Paper commissioned by the Task Group on Training for Technicians for Capacity Development (OEKD/ FAO) and the Education for Rural People Flagship Partnership.

Klinck, M., Iuris, B., Louw, D. A. \& Peens, B. (1999) A South African perspective on children's rights: Pertinent issues in remedial and protection interventions. Medicine and Law, 19, 253-273.

Lansdown, G. (2001) Promoting children's participation in democratic decision-making. UNICEF Innocenti Research Centre.

Loeb, E. M. \& Eide, A. H. (2004). Exploring living conditions among people with disabilities in southern areas in Africa. In: J. Tøssebro \& A. Kitelsaa (eds). Exploring disabled people's living conditions. Lund: Studentlitteratur.

Lowden, J. (2002) Children's rights: A decade of dispute. Journal of Advanced Nursing, 37, 100-107.

Lurie, J. \& Tjelflaat, T. (2012) Children's Rights and the UN Convention on the Rights of the Child: Monitoring and Implementation in Norway. Dialogue in Practice, 1, 41-56.

Naidoo, S. (2008) How successful is South Africa in decreasing communicable diseases? South African Journal of Epidemiology and Infection, 23(4), 10-12.

O'Neill, T. \& Zinga, D. (2008) Children's rights: Multidisciplinary approaches to participation and protection, University of Toronto Press.

Peterson-Badali, M., Ruck, M. D. \& Ridley, E. (2003) College Students' Attitudes toward Children's Nurturance and Self-Determination Rights. Journal of Applied Social Psychology, 33, 730-755.

Rafferty, Y. (2007) Children for sale: Child trafficking in Southeast Asia. Child Abuse Review, 16, 401-422. 
Renaut, A. (2002) La libération des enfants: Contribution philosophique à une histoire de l'enfance, Bayard Jeunesse.

Ruck, M. D., Abramovitch, R. \& Keating, D. P. (1998) Children's and Adolescents' Understanding of Rights: Balancing Nurturance and Self-Determination. Child Development, 69, 404-417.

Ruck, M. D., Peterson-Badali, M. \& Day, D. M. (2002) Adolescents' and mothers' understanding of children's rights in the home. Journal of Research on Adolescence, 12, 373-398.

Saleh, L. (1999) The rights of children with special needs: From rights to obligations and responsibilities. Prospects, 29, 203-216.

Skelton, T. (2007) Children, young people, UNICEF and participation. Children's Geographies, 5, 165-181.

South Africa, Republic of. (1996) Constitution of the Republic of South Africa, Chapter 2: Bill of Rights. Available at: http://www.gov.za/documents/constitution/chapter-2-bill-rights (1 June 2015).

Statistics South Africa. (2011) General Household Survey. Available at: http://microdata.worldbank.org/index.php/catalog/1297 (1 June 2015).

Tomaševski, K. (2001) Human rights obligations: Making education available, accessible, acceptable and adaptable. Raoul Wallenberg Institute of Human Rights and Humanitarian Law.

Tregenna, F. \& Mfanafuthi, T. (2012) Inequality in South Africa: The distribution of income, expenditure and earnings. Development Southern Africa, 29, 1, 35-61.

Unicef. (2005) Child Poverty in Rich Countries. Innocenti Report Card No. 6. UNICEF Innocenti Research Centre, Florence.

Unicef. (2009) The state of the world's children, Special edition. Available at: www.unicef.org/sowc09/ (3 June 2015).

United Nations. (1989) Convention on the Rights of the Child, 20 November 1989. Annual Review of Population Law, 16, 95, 485-501.

Wang, H. L. (2009) Should all Students with Special Educational Needs (SEN) be included in Mainstream Education Provision? A Critical Analysis. International Education Studies, 2,

Ward, T. \& Stewart, C. (2008) Putting human rights into practice with people with an intellectual disability. Journal of Developmental and Physical Disabilities, 20, 297-311.

Venter, E., Kok, J. \& Myburgh, C. (1996) Die skool en die kind se menseregte: 'n empiriese studie. South African Journal of Education, 16, 21-26.

Woodhouse, B. B. (2006) The Family-Supportive Nature of the UN Convention on the Rights of the Child. In: The UN Convention on the Rights of the Child: An analysis of treaty provisions and implications of US ratification, 37-49. 
Thank you for participating in our study !

Participant

number

Please answer all of the questions below.

Mark with a cross $(X)$ in the appropriate block.

School

number

\section{SECTION 1}

1. Are you the primary caregiver of the child with a disability?

\begin{tabular}{|l|l|}
\hline Yes & No \\
\hline
\end{tabular}

2. What is your relationship with the child with the disability?

Father Mother

Other

(please specify)

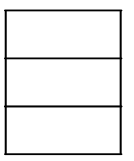

3. In what language do you raise your children? (mark all)

Afrikaans English

isiZulu

Xitsonga Other

(Please specify)

4. What is your current relationship status?

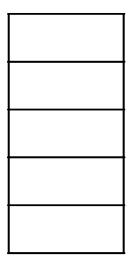

Married

In a constant relationship

Single parent

Other (Please specify)

5. What is your current work status?
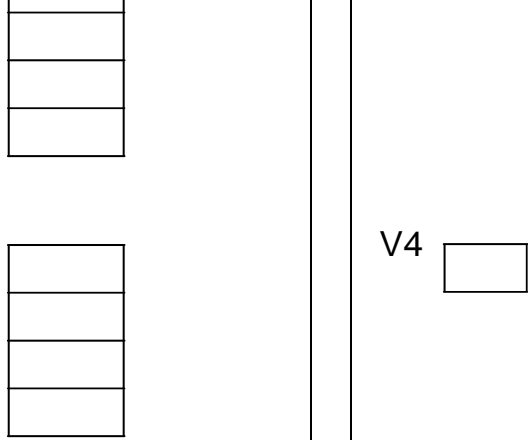

Unemployed

Part time employed

Full time employed

6. What is your age?

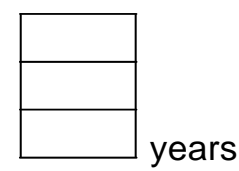

V2

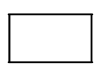

V3
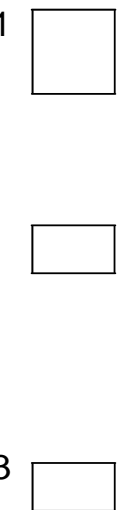

3

V5

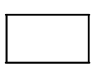

7. What is the highest educational qualification that you completed?

Grade 10 or less

Grade 12

1-4 years after school

5-7 years after school

8-10 years after school

Other (please specify)

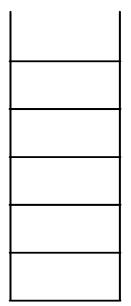

V6

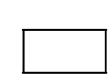

V7

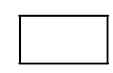


8. What is the total income of your household?

Less than R60 000 per annum

More than R60 000 per annum

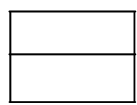

9. How many adults are living in your house?

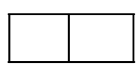

V9

10. How many children, according to each age group, are living in your house?

Children 1 to 2 years

Children 3 to 4 years

Children Older than 5 years

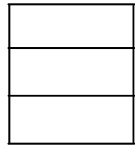

11. What is the gender of your child with a disability?

Male

Female

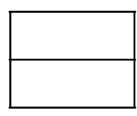

12. How old is your child with a disability?

Years Months

13. Does your child with the disability have a birth certificate?
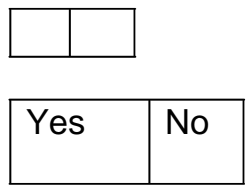

14. Did your child already have the disability at birth?

\begin{tabular}{|l|l|}
\hline Yes & No \\
\hline
\end{tabular}

15. Does your child with the disability have access to medical services?

\section{SECTION 2:}

\begin{tabular}{|l|l|}
\hline Yes & No \\
\hline
\end{tabular}

16. When comparing your child with other children, did the child sit, stand and walk later than other children?

17. When comparing with other children, does your child have problems seeing during the day or at night?

\begin{tabular}{|l|l|}
\hline Yes & No \\
\hline
\end{tabular}

If YES, does your child have something like glasses at home to help him/her to see?
Always
Sometimes
Seldom
Never

18. Does your child experience hearing problems?

\begin{tabular}{|l|l|}
\hline Yes & No \\
\hline
\end{tabular}

If YES, does your child have something like a hearing aid or cochlear implant to help him/her hear?

\section{Always \\ Sometimes \\ Seldom \\ Never}

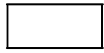

$\mathrm{V} 11$

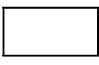

12

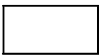

V13

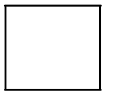

V14

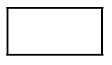

V15

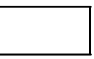

19. Does your child understand when instructions are given to him/her?

\begin{tabular}{|l|l|}
\hline Yes & No \\
\hline
\end{tabular}

If YES, does your child have someone at home to help him/her to understand instructions?

\section{Always}

Sometimes

Seldom

Never

V22

V16

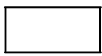

V17

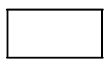

V18

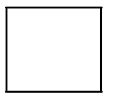

V19
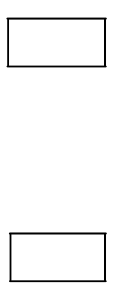

V21

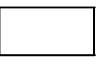


20. Does your child experience problems to walk or move his/her arms or have weakness and/or stiffness in his/her arms and legs?

\begin{tabular}{|l|l|}
\hline Yes & No \\
\hline
\end{tabular}

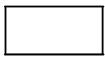

If YES, does your child have something like a wheelchair or walking frame at home to help him/her to move around?

\begin{tabular}{|c|c|c|c|c|}
\hline Always & Sometimes & Seldom & & Never \\
\hline \multicolumn{5}{|c|}{$\begin{array}{l}\text { 21. Does your child get epileptic fits, convulsions or does he/she lose } \\
\text { consciousness? }\end{array}$} \\
\hline \multicolumn{5}{|c|}{ If YES, does your child get the necessary medication at home? } \\
\hline Always & Sometimes & Seldom & & Never \\
\hline \multicolumn{5}{|c|}{$\begin{array}{l}\text { 22. Can your child talk, or make him/herself understandable by using } \\
\text { recognizable words? }\end{array}$} \\
\hline & & & Yes & No \\
\hline
\end{tabular}
to help him/her speak?

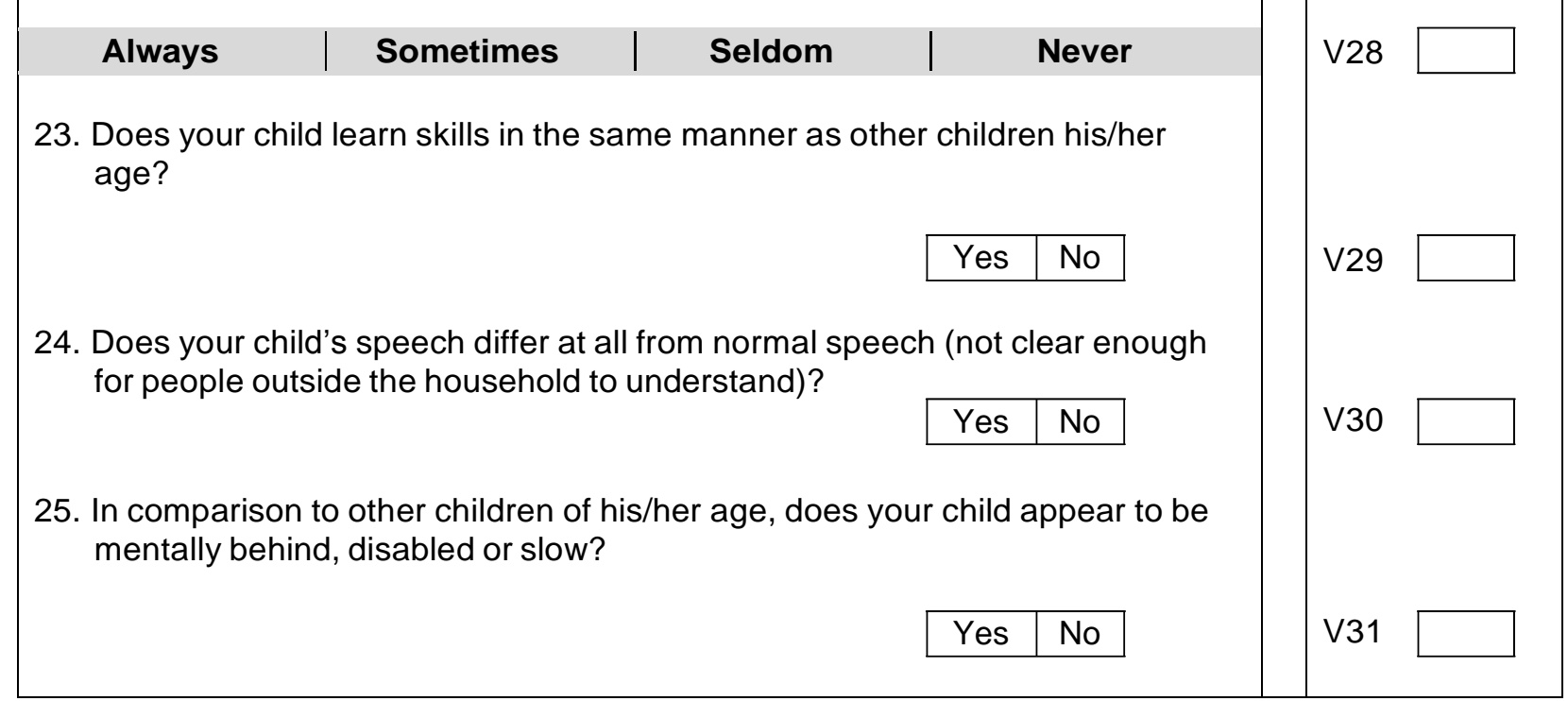




\section{SECTION 3:}

Indicate to what extent the following questions are applicable to your child. Mark with a cross $(X)$ in the appropriate block

\begin{tabular}{|c|c|c|c|c|c|}
\hline $\begin{array}{l}\text { 26. Does your child have clean water to } \\
\text { drink at home? }\end{array}$ & Always & Sometimes & Seldom & Never & V32 \\
\hline $\begin{array}{l}\text { 27. Does your child have food to eat at } \\
\text { home? }\end{array}$ & Always & Sometimes & Seldom & Never & V33 \\
\hline $\begin{array}{l}\text { 28. Does your child have his/her own bed } \\
\text { to sleep in at home? }\end{array}$ & Always & Sometimes & Seldom & Never & V34 \\
\hline $\begin{array}{l}\text { 29. Does your child have something to play } \\
\text { with at home? }\end{array}$ & Always & Sometimes & Seldom & Never & V35 \\
\hline $\begin{array}{l}\text { 30. Does your child like it if someone } \\
\text { becomes angry at him/her at home? }\end{array}$ & Always & Sometimes & Seldom & Never & V36 \\
\hline $\begin{array}{l}\text { 32. Is there someone who cares for and } \\
\text { protects him/her child at home? }\end{array}$ & Always & Sometimes & Seldom & Never & V37 \\
\hline $\begin{array}{l}\text { 33. Does your child have friends to play } \\
\text { with at home? }\end{array}$ & Always & Sometimes & Seldom & Never & V38 \\
\hline $\begin{array}{l}\text { 34. Are you of the opinion that the school is } \\
\text { the best placement for your child? }\end{array}$ & Always & Sometimes & Seldom & Never & V39 \\
\hline \multicolumn{3}{|c|}{ 35. Are you of the opinion that your child has rights? } & Yes & No & V40 \\
\hline \multicolumn{6}{|c|}{$\begin{array}{l}\text { 36. If you answered "yes" to question } 35 \text {, please list in order of importance the child's } \\
\text { rights that you can think of. }\end{array}$} \\
\hline \multicolumn{5}{|c|}{ i } & V41 \\
\hline \multicolumn{5}{|c|}{ ii } & V42 \\
\hline \multicolumn{5}{|c|}{ iii. } & V43 \\
\hline \multicolumn{5}{|c|}{ vi } & V44 \\
\hline \multicolumn{5}{|c|}{ 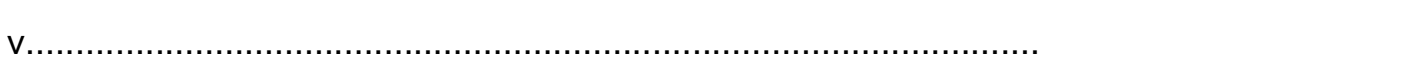 } & V45 \\
\hline
\end{tabular}

